\title{
MATHEMATICAL MODEL OF THE DOWNWARD TWO-PHASE FLOW OF A HEAT-TRANSFER AGENT IN AN INJECTION WELL
}

\author{
N.G. Musakaev ${ }^{1,2}$, S.L. Borodin ${ }^{2}$, S.P. Rodionov ${ }^{2,3}$ \\ ${ }^{1}$ Industrial University of Tyumen, Tyumen, Russian Federation \\ ${ }^{2}$ Tyumen Branch of Khristianovich Institute of Theoretical and Applied Mechanics \\ of the Siberian Branch of the Russian Academy of Sciences, Tyumen, Russian Federation \\ ${ }^{3}$ RUDN University, Moscow, Russian Federation \\ E-mails: musakaev@ikz.ru, borodin@ikz.ru,rodionovsp@bk.ru
}

\begin{abstract}
At the present time, the main method of developing highly viscous and bituminous oil reservoirs is the injection of hot water or steam into such reservoirs. When injecting heat-transfer agent into a porous reservoir, its characteristics at the wellhead are known. It is important to know the parameters of a heat-transfer agent (pressure, temperature, mass content of steam in a two-phase mixture "water-steam", etc.) directly at the reservoir entrance. In order to calculate various parameters of a heat-transfer agent along the injection well depth (including the bottomhole), we propose a mathematical model of the downward flow of a hot "water-steam" mixture in a vertical channel. The model takes into account phase transitions occurring in a two-phase "water-steam" mixture, and external heat exchange of the well product with surrounding rocks (including permafrost). Based on the proposed mathematical model, we develop an algorithm to solve a quasistationary problem. In this case, we use the Runge-Kutta method in order to solve the system of differential equations describing the stationary flow of a heat-transfer agent in a well. Also, in order to solve the non-stationary problem of temperature distribution in the rocks that surround the well (including permafrost), we use the author enthalpy method with implicit scheme. For each time moment, the developed software allows to find the distributions along the well depth of various parameters of the downward two-phase flow, taking into account external heat exchange, as well as the temperature distribution in the rocks that surround the well and the permafrost thawing radius.
\end{abstract}

Keywords: two-phase flow; heat-transfer agent; injection well; permafrost; thawed zone.

\section{Introduction}

The last decades are characterized by an increase in the consumption of hydrocarbons, especially in developing countries [1]. At the same time, the actual problem of oil production is the depletion of light oil reserves not only in Russia, but all over the world. Therefore, reservoirs with high-viscosity oil are increasingly involved in the development. Existing methods for developing such reservoirs allow to achieve a final oil recovery ratio, which is no higher than $0,25-0,29$. The most common methods of developing highviscosity oil reservoirs are thermal [2-4]. Many researchers consider the steam injection into a reservoir as the most promising thermal method of developing high-viscosity oil reservoirs [3-6]. Due to the latent heat of vaporization, steam has higher heat content than hot water at the same temperature [4]. In addition, water steam has higher oil-displacing properties than hot water. Therefore, water steam is considered to be a technologically more efficient heat-transfer agent, although hot water can be more preferable for practical use in some specific cases. In production practice, in order to implement thermal effects on the reservoir saturated with high-viscosity oil, a saturated water steam (i.e., a mixture 
of steam and water) is used. Indeed, the preparation of a saturated water steam requires less thorough chemical preparation than the preparation of a dry steam [6-8].

During implementation of technologies of thermal effects on the reservoir saturated with high-viscosity oil, we know the characteristic of a "water-steam" mixture at the outlet of the device for producing steam, which is located at the wellhead. The most important parameters are the temperature and steam content of a heat-transfer agent directly at the well bottom. In order to calculate these and other parameters, it is necessary to obtain a mathematical description of hydrodynamic and thermophysical processes occurring in the injection well. In addition, a number of oil reservoirs of the Russian Federation are located in permafrost regions. Depending on the geographic zone, the depth of the permafrost layer can exceed $600 \mathrm{~m}$. The permafrost zone is characterized by abnormally low temperature and low geothermal gradients. Therefore, for proper modelling of the steam-water mixture flow in a well in such conditions, it is necessary to take into account both the change in thermodynamic parameters when the fluid moves in the wellbore to the well bottom, and the heat exchange of the fluid with frozen rocks, taking into account the frozen rocks thawing.

This paper presents the results of mathematical modelling of the processes occurring in an injection well and surrounding rocks (including frozen rocks), when the heat-transfer agent is pumped into an oil-saturated reservoir.

\section{Main Equations}

Consider the following problem statement. Suppose that a heat-transfer agent (a steam-water mixture) moves in a vertical well with inner radius $r_{w}$, from the wellhead to the well bottom. The parameters of the heat-transfer agent are known at the wellhead (at the outlet of heater or steam generator); the heat-transfer agent mass flow rate $m$ is constant. The well passes through permafrost. Since the transient processes in wells are rather short-lived, we consider the well operation mode to be stationary, and the two-phase flow in the well to be steady. We direct axis $z$ vertically downwards, $r$ is the radial axis. The origin of coordinates coincides with the wellhead (Fig. 1).

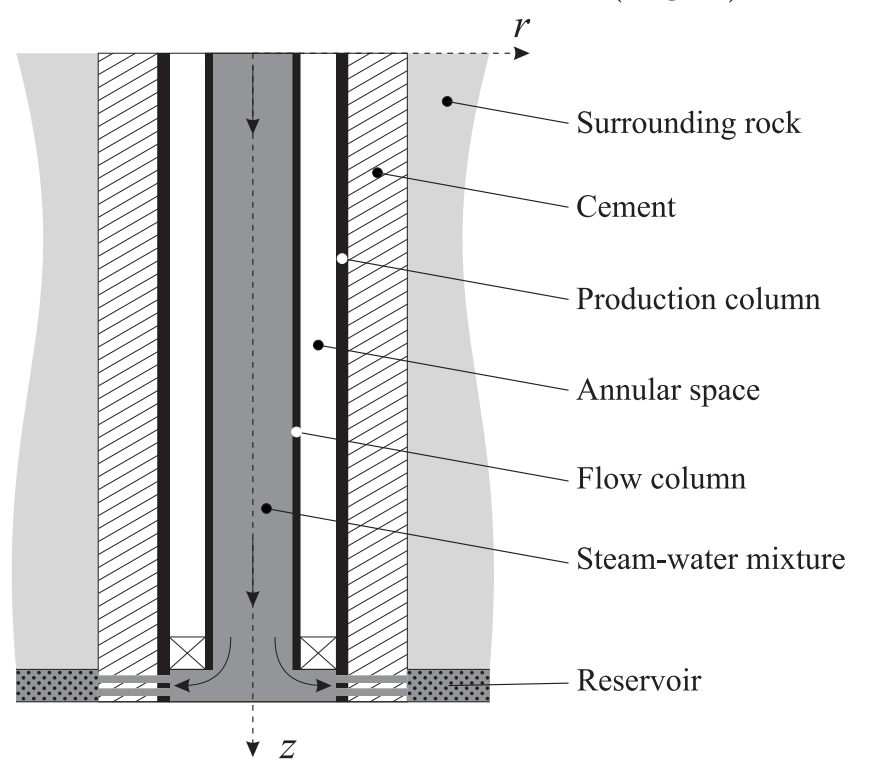

Fig. 1. Scheme of an injection well with heat transfer agent 
In order to construct a mathematical model, we assume the following. First, for each well section, the temperature is the same for both components of two-phase mixture (steam and water). Second, processes of steam condensation or water evaporation occur in the equilibrium mode. Third, in the axial direction of the well, the thermal conductivity is negligible compared with convective heat transfer [9]. Also, we neglect the influence of the seasonal change in the surface temperature. In addition, the rocks surrounding the well are homogeneous and isotropic. Finally, there is no mass transfer of thawed water, when the front of phase transitions moves in frozen rocks [10].

Taking into account the assumptions above, we can write the equations describing a downward two-phase flow in a vertical channel as follows [11-15]:

$$
\begin{gathered}
m_{l}+m_{v}=m=\text { const, } \\
\frac{d p}{d z}=-F_{w}+\left(\rho_{l}^{0}(1-\alpha)+\rho_{v} \alpha\right) g \\
m c \frac{d T}{d z}=\frac{m_{v}}{\rho_{v}^{0}} \frac{d p}{d z}-L_{l v} \frac{d m_{v}}{d z}-Q_{w} \\
k_{v}=\frac{m_{v}}{m}, \quad \rho_{l}^{0}=\text { const, } \quad p=Z_{v} \rho_{v}^{0} R_{v} T \\
m_{l}=\rho_{l}^{0}(1-\varphi) S W, \quad m_{v}=\rho_{v}^{0} \varphi S W, \quad S=\pi r_{w}^{2}, \\
F_{w}=\frac{\lambda_{w}}{4 r_{w}}\left(\rho_{l}^{0} \frac{(1-\varphi)^{2}}{1-\alpha}+\rho_{v}^{0} \frac{\varphi^{2}}{\alpha}\right) W^{2}, \quad \lambda_{w}=0,067\left[\frac{158}{\operatorname{Re}}+\frac{\varepsilon}{r_{w}}\right]^{1 / 5}, \\
\varphi=\left(1+\frac{\rho_{v}^{0} m_{l}}{\rho_{l}^{0} m_{v}}\right)^{-1}, \quad W=\frac{1}{S}\left(\frac{m_{l}}{\rho_{l}^{0}}+\frac{m_{v}}{\rho_{v}^{0}}\right), \\
m c=m_{l} c_{l}+m_{v} c_{v}, \quad Q_{w}=2 \pi r_{w} q_{w} .
\end{gathered}
$$

Here the subscript $l$ or $v$ corresponds to the parameter related to liquid or vapour, respectively; $m_{i}(i=l, v)$ is the mass flow rate of the $i$-th phase through the tubing section with coordinate $z ; \rho_{i}^{0}$ and $c_{i}(i=l, v)$ are the true density and specific heat capacity at constant pressure of the $i$-th phase, respectively; $k_{v}$ is the mass fraction of vapour in the water-vapour mixture (dryness of steam); $\lambda_{w}$ is the coefficient of friction between the steam-water mixture flow and the inner tubing surface; Re is the Reynolds number; $\varepsilon$ is the size of roughness; $\varphi$ is the volumetric flow vapour content; $R_{v}$ is the gas constant for water steam; $L_{l v}$ is the specific heat of vaporization; $q_{w}$ is the intensity of heat removal per the well unit area. In order to write equation (2) for calculating pressure, we neglect the terms that are associated with inertial effects.

In order to calculate the volumetric vapour content value $\alpha$, we use the following relation [14]:

$$
\alpha=\left\{\begin{array}{l}
0,833 \varphi, \quad \varphi \leq 0,9 \\
{\left[0,833 \varphi+0,167\left(1+\frac{\rho_{l}^{0}(1-\varphi)}{\rho_{v}^{0} \varphi}\right)^{-1}\right] \varphi, \quad \varphi>0,9 .}
\end{array}\right.
$$

The supercompressibility coefficient for the vapour $Z_{v}$ is found on the basis of the LatonovGurevich equation [16]:

$$
Z_{v}=\left[0,17376 \cdot \ln \left(T / T_{k}\right)+0,73\right]^{p / p_{k}}+0,1 \cdot p / p_{k},
$$

where $T_{k}$ and $p_{k}$ are the empirical critical parameters for vapour. 
The conditions on the wellhead (subscript or) can be set as follows:

$$
z=0: \quad p=p_{\text {or }}, \quad T=T_{o r}, \quad k_{v}=k_{o r} .
$$

In order to deliver a heat-transfer agent into a reservoir, it is necessary that the bottomhole pressure exceeds the reservoir pressure.

In order to close the system of equations (1) - (3), we set the intensity of heat removal $Q_{w}$ into surrounding rocks. The process of the heat distribution from a well to surrounding rocks can be considered sequentially: heat transfer from the two-phase flow to the well inner wall; heat transfer through the pipes system of the well; distribution of heat in the surrounding rocks, taking into account the possible thawing of frozen rocks.

For the rate $q_{w}$ of heat transfer from the flow to the well inner wall, we can write the following relation $[6,17]$ :

$$
q_{w}=\beta_{w}\left(T-T_{w}\right),
$$

where $T_{w}$ is the temperature of the well inner wall; $\beta_{w}$ is the heat transfer coefficient depending on the structure of the two-phase flow, as well as on the characteristics of the flow in the near-surface layer of the channel wall.

In order to calculate the heat transfer through the well pipes system, we take into account the scheme of a well given in Fig. 1. In this case, for the coefficient of heat transfer through the well pipes system, we can write the following expression [18]:

$$
\beta=\left\{r_{c}\left(\frac{\ln \left(r_{1} / r_{w}\right)}{\lambda_{\text {met }}}+\frac{\ln \left(r_{i s} / r_{1}\right)}{\lambda_{i s}}+\frac{\ln \left(r_{2} / r_{i s}\right)}{\lambda_{a s}}+\frac{\ln \left(r_{3} / r_{2}\right)}{\lambda_{\text {met }}}+\frac{\ln \left(r_{c} / r_{3}\right)}{\lambda_{b}}\right)\right\}^{-1},
$$

where $r_{w}$ and $r_{1}$ are the inner and outer radius of a flow column, respectively; $r_{i s}=r_{1}+\Delta r$; $\Delta r$ is the thickness of an insulating layer (if available); $r_{2}$ and $r_{3}$ are the inner and outer radius of a production column, respectively; $r_{c}$ is the outer well radius; $\lambda_{m e t}, \lambda_{i s}, \lambda_{a s}$ and $\lambda_{b}$ are the coefficients of thermal conductivity of the tubes metal, insulating layer, the matter in the well annular space and cement, respectively.

If the matter in the well annular space is in the state of thermogravitational convection, then this process can be taken into account in the calculations by the following multiplier for the coefficient $\lambda_{\text {as }}[3]$ :

$$
\xi=0,049(\mathrm{Gr} \cdot \operatorname{Pr})^{1 / 3} \operatorname{Pr}^{0,074},
$$

where Gr and Pr are the Grashof and Prandtl numbers.

Since the conditions of the equality of heat flows must be satisfied, the following expression can be written for the temperature on the well inner wall:

$$
T_{w}=\frac{r_{w} \beta_{w} T+r_{c} \beta T_{c}}{r_{w} \beta_{w}+r_{c} \beta}
$$

where $T_{c}$ is the temperature on outside well surface.

The non-stationary problem of heat distribution in the surrounding rocks located below the frozen zone is described by the following system of equations [10]:

$$
\begin{gathered}
t>0, \quad r_{c}<r<\infty: \quad \frac{\partial T_{e x t}}{\partial t}=\chi_{e x t} \frac{1}{r} \frac{\partial}{\partial r}\left(r \frac{\partial T_{e x t}}{\partial r}\right), \\
t=0, \quad r_{c}<r<\infty: \quad T_{e x t}=T_{g e o}, \\
t>0, \quad r=r_{c}: \quad-\lambda_{e x t} \frac{\partial T_{e x t}}{\partial r}=\beta\left(T_{w}-T_{c}\right), \\
t>0, \quad r \rightarrow \infty: \quad T_{\text {ext }}=T_{g e o},
\end{gathered}
$$


where $T_{\text {ext }}, \lambda_{\text {ext }}$ and $\chi_{\text {ext }}$ are the temperature, thermal conductivity and thermal diffusivity of surrounding rocks, respectively; $T_{g e o}$ is the geothermal temperature.

Taking into account the possible permafrost thawing, for the problem of heat transfer in frozen rocks we can write the following:

$$
\begin{gathered}
t>0, \quad r_{c}<r \leq r_{c}+\theta: \quad \frac{\partial T_{t h}}{\partial t}=\chi_{t h} \frac{1}{r} \frac{\partial}{\partial r}\left(r \frac{\partial T_{t h}}{\partial r}\right), \\
t>0, \quad r_{c}+\theta<r<\infty: \quad \frac{\partial T_{f r}}{\partial t}=\chi_{f r} \frac{1}{r} \frac{\partial}{\partial r}\left(r \frac{\partial T_{f r}}{\partial r}\right), \\
t>0, \quad r=r_{c}: \quad-\lambda_{t h} \frac{\partial T_{t h}}{\partial r}=\beta\left(T_{w}-T_{c}\right), \\
\left.\lambda_{f r} \frac{\partial T_{f r}}{\partial r}\right|_{r=r_{c}+\theta+0} \quad-\left.\lambda_{t h} \frac{\partial T_{t h}}{\partial r}\right|_{r=r_{c}+\theta-0}=\rho w L_{i} \frac{d \theta}{d t}, \\
t=0, \quad r_{c}<r<\infty: \quad T_{f r}=T_{g e o}, \\
t>0, \quad r \rightarrow \infty: \quad T_{f r}=T_{g e o},
\end{gathered}
$$

where $T_{f r}$ and $\lambda_{f r}$ are the temperature and coefficient of thermal conductivity of frozen rocks; $T_{t h}$ and $\lambda_{t h}$ are the temperature and coefficient of thermal conductivity of thawed rocks; $w$ is the ice content; $\rho$ is the rock density; $L_{i}$ is the specific heat of ice melting; $\theta$ is the length of thawed zone.

\section{Numerical Implementation}

Let us describe the steps of the proposed computational algorithm for calculating the parameters of the downward two-phase flow in an injection well, taking into account the thermal interaction of the well product with surrounding rocks (including frozen rocks).

1. Set the parameters of a well, fluids and surrounding rocks. At the wellhead, set the following values: dryness of steam, pressure, temperature, and the mass flow rate of a heat-transfer agent. These parameters remain constant for all time of calculation. At the initial time moment $(t=0)$, the temperature on the outer surface of the well $T_{c}(z)$ is equal to geothermal temperature.

2 . For the current time point $t$, solve the Cauchy problem on the basis of the system of equations (1) - (3), taking into account known values at the wellhead (4). In this paper, the system of ordinary differential equations (1) - (3) is solved by the fourth-order RungeKutta method. The intensity of heat removal to the surrounding rocks $Q_{w}$ is calculated taking into account the known temperature on the outer surface of the well for each value of $z$. Therefore, in the interval from the wellhead to the well bottom, the steam-water mixture flow parameters are determined, including the temperature distribution $T(z)$.

3. Taking into account the obtained values of $T(z)$ for all values of $z$, calculate the temperature distribution in the rocks surrounding the well for the next time step. This distribution is determined on the basis of the solution to the system of equations (10)(15) (for frozen rocks) or the system of equations (6) - (9) (for rocks located below the frozen zone). In this paper, this system of equations is solved using an implicit scheme and the author's enthalpy method [19]. Therefore, for each value $z$, we obtain the temperature distribution in the rocks surrounding the well, including the temperature on the outer surface of the well $T_{c}(z)$. Also, for the rocks located in the frozen zone, we determine the thawed zone radius $\theta(z)$. 
4. Taking into account the values $T_{c}(z)$, which was found in Step 3 for the next time step, go to Step 2. Calculations are carried out until the end of calculation time.

Therefore, according to the proposed algorithm, determining the parameters of the heat-transfer agent in an injection well, taking into account thermal interaction with surrounding rock, is quasistationary and splits into two problems. The first problem deals with the steady downward two-phase flow in the well, taking into account heat losses to the surrounding rocks. In the second problem, the unsteady distribution of heat in the surrounding rocks is investigated, taking into account possible thawing of permafrost.

According to the proposed algorithm, computer code was developed. For each time point, this code allows to find the distribution over the well depth of various parameters of a downward two-phase flow, taking into account heat losses to the surrounding rocks.

\section{Results of Trial Calculations}

Fig. 2 shows the change in the temperature, pressure and mass concentration of vapour in the vapour-water mixture depending on the depth. Fig. 3 shows temperature fields in the well and surrounding rocks. During the calculations, the following values of the parameters were taken $[3,12,20]: m=0,5 \mathrm{~kg} / \mathrm{s} ; T_{o r}=307^{\circ} \mathrm{C} ; p_{\text {or }}=9,6 \mathrm{MPa} ; k_{o r}=0,9 ; r_{w}=0,031$ $\mathrm{m} ; r_{1}=0,036 \mathrm{~m} ; r_{2}=0,076 \mathrm{~m} ; r_{3}=0,084 \mathrm{~m} ; r_{c}=0,125 \mathrm{~m} ; p_{k}=21,8 \mathrm{MPa} ; T_{k}=647$ $\mathrm{K} ; \lambda_{l}=0,5 \mathrm{~W} /(\mathrm{m} \cdot \mathrm{K}) ; \lambda_{m e t}=45 \mathrm{~W} /(\mathrm{m} \cdot \mathrm{K}) ; \lambda_{b}=1,1 \mathrm{~W} /(\mathrm{m} \cdot \mathrm{K}) ; c_{l}=4200 \mathrm{~J} /(\mathrm{kg} \cdot \mathrm{K}) ;$ $R_{v}=461 \mathrm{~J} /(\mathrm{kg} \cdot \mathrm{K}) ; \mu_{l}=1,2 \cdot 10^{-5} \mathrm{~kg} /(\mathrm{m} \cdot \mathrm{s}) ; \varepsilon=0,00001 \mathrm{~m} ; g=9,8 \mathrm{~m} / \mathrm{s}^{2} ;$ the initial temperature of the rock at the wellhead is $-2^{\circ} \mathrm{C}$; the frozen rocks depth is $200 \mathrm{~m}$; the well depth is $1000 \mathrm{~m}$. There is no thermal insulation on the outer surface of the well flow column; there is water in the well annular space. The values of $c_{v}, \lambda_{v}, \mu_{v}$ were determined by interpolating the tabular data for water steam [3].
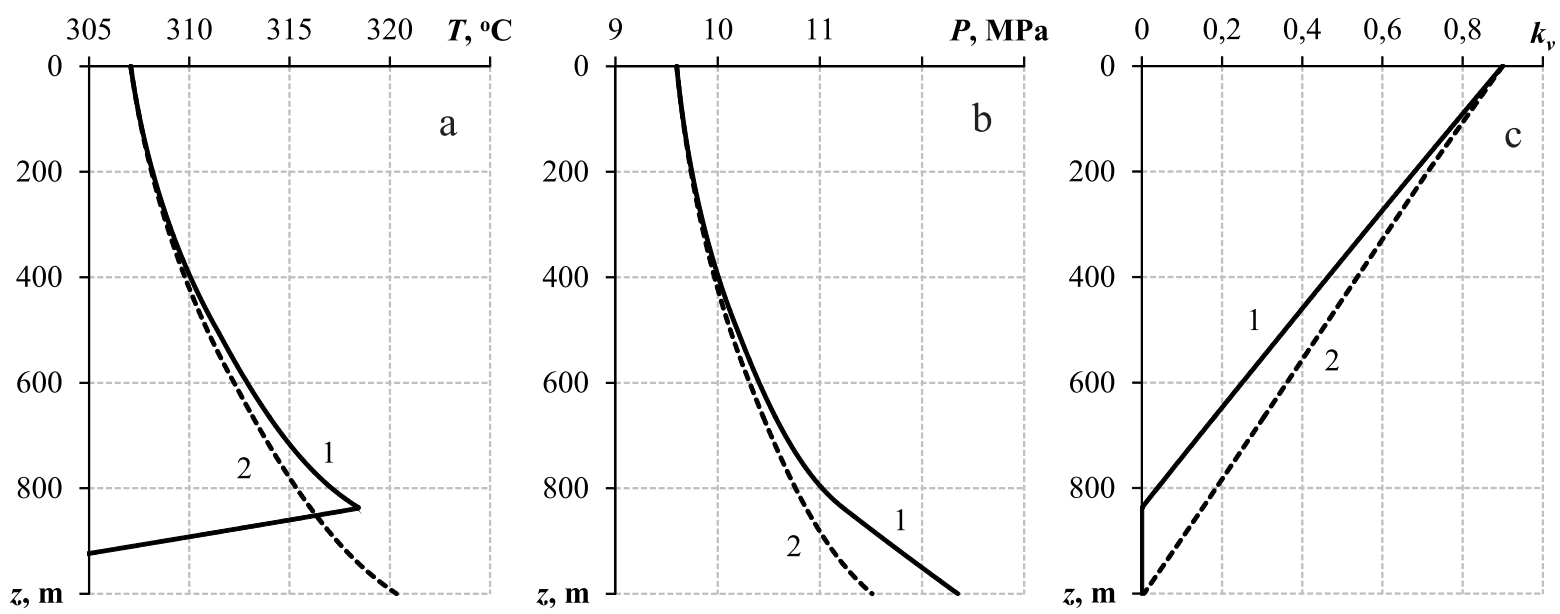

Fig. 2. Distributions of the temperature (a), pressure (b), and mass concentration of vapour $(\mathrm{c})$ in the two-phase flow along the well height. Solid lines correspond to the initial time moment, while dashed lines correspond to the time moment equal to 3 days after the start of the heat-transfer agent injection

Fig. 2 shows that as the steam-water mixture moves in the well, there is a drop in the mass concentration of steam due to its condensation. For the parameters taken in the calculations at the initial time moment, all the steam condensed without reaching the 
well bottom. Three days after the start of the steam-water mixture injection, due to the heating of the rocks surrounding the well (Fig. 3), there is gradually increase in the twophase mixture temperature at the well bottom. Fig. 2 shows that the steam is delivered to the well bottom in 3 days. At the same time, the density of the two-phase mixture decreases, and, therefore, there is the corresponding decrease in the pressure gradient. Also, note a smaller warming up of the frozen rocks (Fig. 3) due to the additional heat consumption for the ice melting.
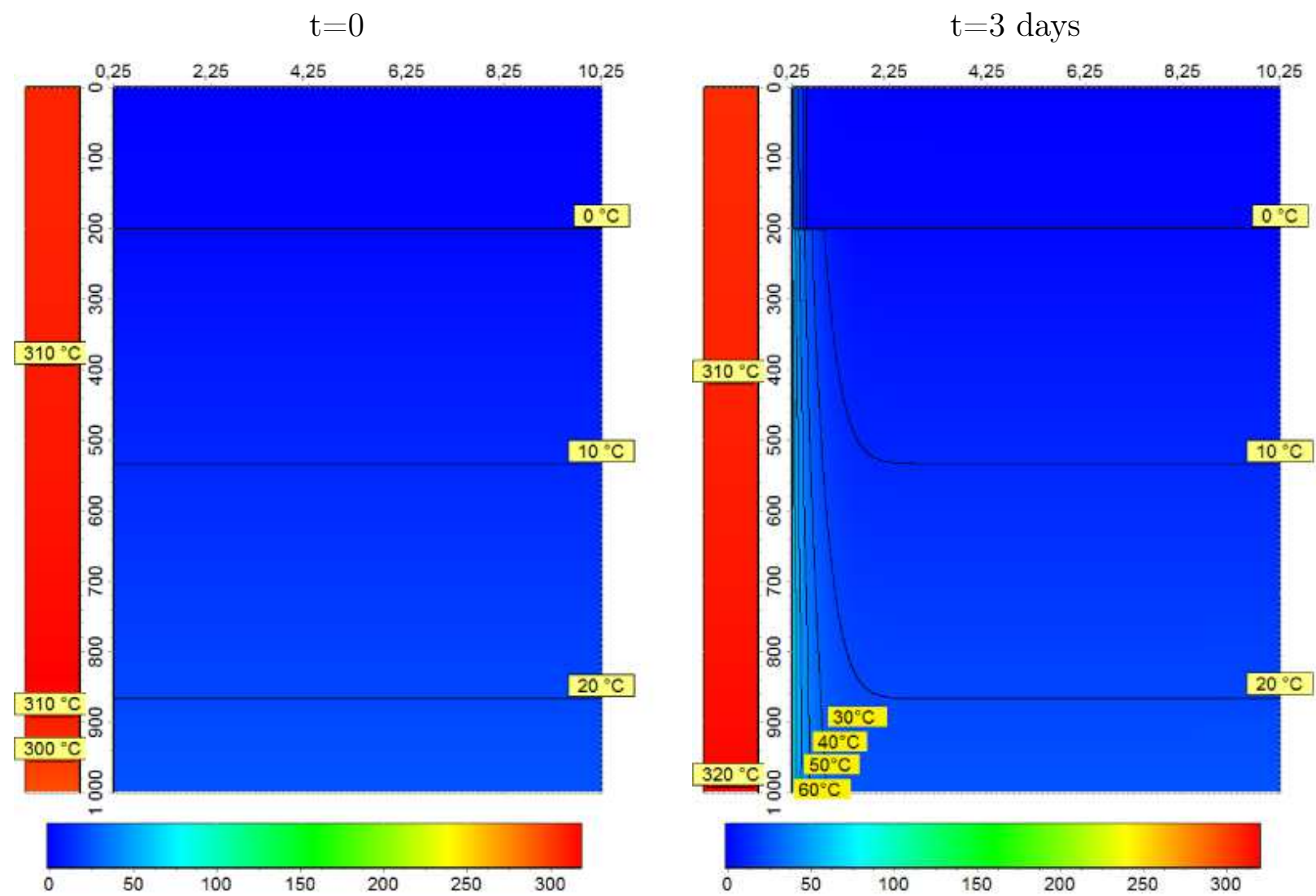

Fig. 3. Temperature distribution in the rocks surrounding the well at the beginning of the heat-transfer agent injection (left figure) and after 3 days (right figure)

\section{Conclusion}

In this work, we propose a mathematical model of the processes occurring during a heat-transfer agent movement in an injection well. This model is based on the equations of the multiphase media mechanics. The model takes into account phase transitions occurring in the two-phase "water-steam" mixture, as well as the external heat exchange of the well product with the surrounding rocks (including permafrost). We construct an algorithm that allows to calculate the parameters of the heat-transfer agent over the injection well depth, as well as to calculate the temperature distribution in the surrounding rocks and the melting radius of permafrost for different times of the well operation. Also, we implement the algorithm in a program.

Acknowledgements. The reported study was funded by the Russian Science Foundation (project no. 18-19-00049). 


\section{References}

1. Makogon Y.F., Holditch S.A., Makogon T.Y. Natural Gas-Hydrates - A Potential Energy Source for the 21st Century. Journal of Petroleum Science and Engineering, 2007, vol. 56, pp. 14-31. DOI: $10.1016 /$ j.petrol.2005.10.009

2. Ter-Sarkisov R.M. Razrabotka $i$ dobycha trudnoizvlekayemykh zapasov uglevodorodov [Development and Production of Hard-to-Recover Hydrocarbon Reserves]. Moscow, Nedra, 2005. (in Russian)

3. Burger J., Sourieau P., Combarnous M. Thermal Methods of Oil Recovery. Paris, Technip, 1985.

4. Antoniadi D.G. Nauchnyye osnovy razrabotki neftyanykh mestorozhdeniy termicheskimi metodami [Scientific Basis for the Development of Oil Fields by Thermal Methods]. Moscow, Nedra, 1995. (in Russian)

5. Malofeyev G.E., Mirsayetov O.M., Cholovskaya I.D. Nagnetaniye v plast teplonositeley dlya intensifikatsii dobychi nefti $i$ uvelicheniya nefteotdachi [Injection into the Reservoir of Coolants for the Intensification of Oil Production and Increased Oil Recovery]. Izhevsk, Institut kompyuternykh issledovaniy, 2008. (in Russian)

6. Thomas S. Enhanced Oil Recovery - An Overview. Oil and Gas Science and Technology, 2008, vol. 63, no. 1, pp. 9-19. DOI: 10.2516/ogst:2007060

7. Shagapov V.S., Yumagulova Y.A., Gizzatullina A.A. High-Viscosity Oil Filtration in the Pool Under Thermal Action. Journal of Engineering Physics and Thermophysics, 2018, vol. 91, no. 2, pp. 300-309. DOI: 10.1007/s10891-018-1749-4

8. Willhite G.P. Over-All Heat Transfer Coefficients in Steam and Hot Water Injection Wells. Journal of Petroleum Technology, 1967, vol. 19, no. 5, pp. 607-615. DOI: 10.2118/1449-PA

9. Kutushev A.G., Rusanov A.S. Non-Isothermal Motion of Vapour-Liquid Mixture in a Well. Oil and Gas Studies, 2008, no. 4, pp. 39-45. (in Russian)

10. Medvedskiy R.I. Stroitelstvo $i$ ekspluatatsiya skvazhin na neft $i$ gaz v vechnomerzlykh porodakh [Construction and Operation of Oil and Gas Wells in Permafrost]. Moscow, Nedra, 1987. (in Russian)

11. Nigmatulin R.I. Dynamics of Multiphase Media. N.Y., Hemisphere Publisher Corporation, 1991.

12. Shagapov V.Sh., Musakaev N.G., Khabeev N.S., Bailey S.S. Mathematical Modelling of TwoPhase Flow in a Vertical Well Considering Paraffin Deposits and External Heat Exchange. International Journal of Heat and Mass Transfer, 2004, vol. 47, no. 4, pp. 843-851. DOI: $10.1016 /$ j.ijheatmasstransfer.2003.06.006

13. Musakaev N.G., Borodin S.L. Mathematical Model of the Two-Phase Flow in a Vertical Well with an Electric Centrifugal Pump Located in the Permafrost Region. Heat and Mass Transfer, 2016, vol. 52, no. 5, pp. 981-991. DOI: 10.1007/s00231-015-1614-3

14. Chisholm D. Two-Phase Flow in Pipelines and Heat Exchangers. London, Longman Higher Education, 1983.

15. Kutateladze S.S. Teploperedacha i gidrodinamicheskoye soprotivleniye [Heat Transfer and Hydrodynamic Resistance]. Moscow, Energiya, 1990. (in Russian)

16. Shagapov V.Sh., Urazo R.R., Musakaev N.G. Dynamics of Formation and Dissociation of Gas Hydrates in Pipelines at the Various Modes of Gas Transportation. Heat and Mass Transfer, 2012, vol. 48, no. 9, pp. 1589-1600. DOI: 10.1007/s00231-012-1000-3 
17. Shagapov V.Sh., Chiglintseva A.S., Syrtlanov V.R. Possibility of Gas Washout from a GasHydrate Massif by Circulation of Warm Water. Journal of Applied Mechanics and Technical Physics, 2009, vol. 50, no. 4, pp. 628-637. DOI: 10.1007/s10808-009-0084-0

18. Shagapov V.Sh., Musakaev N.G., Urazov R.R. Mathematical Model of Natural Gas Flow in Pipelines with Allowance for the Dissociation of Gas Hydrates. Journal of Engineering Physics and Thermophysics, 2008, vol. 81, no. 2, pp. 287-296. DOI: 10.1007/s10891-008-0036-1

19. Borodin S.L. Numerical Solution of the Stefan's Problem. Tyumen State University Herald. Physical and Mathematical Modelling. Oil, Gas, Energy, 2015, vol. 1, no. 3, pp. 164-175. (in Russian) DOI: 10.21684/2411-7978-2015-1-3-164-175

20. Bondarev E.A., Rozhin I.I., Argunova K.K. Modelling the Formation of Hydrates in Gas Wells in Their Thermal Interaction with Rocks. Journal of Engineering Physics and Thermophysics, 2014, vol. 87, no. 4, pp. 900-907. DOI: 10.1007/s10891-014-1087-0

Received November 21, 2018

УДК $532.546+519.63$

DOI: $10.14529 / \mathrm{mmp} 190305$

\title{
МАТЕМАТИЧЕСКАЯ МОДЕЛЬ ДВУХФАЗНОГО НИСХОДЯЩЕГО ТЕЧЕНИЯ ТЕПЛОНОСИТЕЛЯ В НАГНЕТАТЕЛЬНОЙ СКВАЖИНЕ
}

\author{
Н.Г. Мусакаев ${ }^{1,2}$, С.Л. Бородин ${ }^{2}$, С.П. Родионов ${ }^{2,3}$ \\ 1 Тюменский индустриальный институт, г. Тюмень, Российская Федерация \\ 2 Тюменский филиал Института теоретической и прикладной механики \\ им. С.А. Христиановича СО РАН, г. Тюмень, Российская Федерация \\ ${ }^{3}$ Российский университет дружбы народов, г. Москва, Российская Федерация
}

В настоящее время основным методом разработки месторождений высоковязких и битумных нефтей является закачка горячей воды или пара в нефтенасыщенный пласт. При закачке теплоносителя в пористый коллектор известны его характеристики на устье скважины. При этом важно знать параметры теплоносителя (давление, температура, массовое содержание пара в двухфазной смеси «вода-пар» и т.д.) непосредственно на входе в пласт. Для расчета различных параметров теплоносителя по глубине нагнетательной скважины (в том числе и на забое) предложена математическая модель нисходящего течения горячей пароводяной смеси в вертикальном канале. В модели учтены фазовые переходы, происходящие в двухфазной смеси «вода-пар», и внешний теплообмен скважины с окружающими горными породами (в том числе и многолетнемерзлыми). На основе предложенной математической модели разработан алгоритм, базируясь на котором, решается квазистационарная задача. При этом методом Рунге - Кутты 4-го порядка точности решается система дифференциальных уравнений, описывающая стационарное течение теплоносителя в скважине, и авторским методом энтальпий с использованием неявной схемы решается нестационарная задача распределения температуры в окружающих скважину породах (в том числе мерзлых). Разработанный программный продукт позволяет найти для каждого момента времени распределение по глубине скважины различных параметров нисходящего двухфазного потока с учетом внешнего теплообмена, а также для различных моментов времени эксплуатации скважины распределение температуры в окружающих горных породах и радиус протаивания многолетнемерзлых пород.

Ключевые слова: двухфазный поток; теплоноситель; нагнетательная скважина; многолетнемерзлые породы; зона протаивания. \& Computer Software (Bulletin SUSU MMCS), 2019, vol. 12, no. 3, pp. 52-62 


\section{Литература}

1. Makogon, Y.F. Natural Gas-Hydrates - A Potential Energy Source for the 21st Century / Y.F. Makogon, S.A. Holditch, T.Y. Makogon // Journal of Petroleum Science and Engineering. - 2007. - V. 56. - P. 14-31.

2. Тер-Саркисов, Р.М. Разработка и добыча трудноизвлекаемых запасов углеводородов / P.М. Тер-Саркисов. - М.: Недра, 2005.

3. Бурже, Ж. Термические методы повышения нефтеотдачи пластов / Ж. Бурже, П. Сурио, М. Комбарну. - М.: Недра, 1989.

4. Антониади, Д.Г. Научные основы разработки нефтяных месторождений термическими методами / Д.Г. Антониади. - М.: Недра, 1995.

5. Малофеев, Г.Е. Нагнетание в пласт теплоносителей для интенсификации добычи нефти и увеличения нефтеотдачи / Г.Е. Малофеев, О.М. Мирсаетов, И.Д. Чоловская. - М.; Ижевск: Институт компьютерных исследований, 2008.

6. Thomas, S. Enhanced Oil Recovery - An Overview / S. Thomas // Oil and Gas Science and Technology. - 2008. - V. 63, № 1. - P. 9-19.

7. Шагапов, В.Ш. Фильтрация высоковязкой нефти в пласте при тепловом воздействии / В.Ш. Шагапов, Ю.А. Юмагулова, А.А. Гиззатуллина // Инженерно-физический журнал. - 2018. - Т. 91, № 2. - С. 319-328.

8. Willhite, G.P. Over-All Heat Transfer Coefficients in Steam and Hot Water Injection Wells / G.P. Willhite // Journal of Petroleum Technology. - 1967. - V. 19, № 5. - P. 607-615.

9. Кутушев, А.Г. Неизотермическое движение парожидкостной смеси в скважине / А.Г. Кутушев, А.С. Русанов // Известия вузов. Нефть и газ. - 2008. - № 4. - С. 39-45.

10. Медведский, Р.И. Строительство и эксплуатация скважин на нефть и газ в вечномерзлых породах / Р.И. Медведский - М.: Недра, 1987.

11. Нигматулин, Р.И. Динамика многофазных сред / Р.И. Нигматулин. - М.: Наука, 1987.

12. Shagapov, V.Sh. Mathematical Modelling of Two-Phase Flow in a Vertical Well Considering Paraffin Deposits and External Heat Exchange / V.Sh. Shagapov, N.G. Musakaev, N.S. Khabeev, S.S. Bailey // International Journal of Heat and Mass Transfer. - 2004. V. 47, № 4. - P. 843-851.

13. Musakaev, N.G. Mathematical Model of the Two-Phase Flow in a Vertical Well with an Electric Centrifugal Pump Located in the Permafrost Region / N.G. Musakaev, S.L. Borodin // Heat and Mass Transfer. - 2016. - V. 52, № 5. - P. 981-991.

14. Чисхолм, Д. Двухфазные течения в трубопроводах и теплообменниках / Д. Чисхолм. М.: Недра, 1986.

15. Кутателадзе, С.С. Теплопередача и гидродинамическое сопротивление / С.С. Кутателадзе. - М.: Энергия, 1990.

16. Shagapov, V.Sh. Dynamics of Formation and Dissociation of Gas Hydrates in Pipelines at the Various Modes of Gas Transportation / V.Sh. Shagapov, R.R. Urazov, N.G. Musakaev // Heat and Mass Transfer. - 2012. - V. 48, № 9. - P. 1589-1600.

17. Шагапов, В.Ш. О возможности вымывания газа из газогидратного массива посредством циркуляции теплой воды / В.Ш. Шагапов, А.С. Чиглинцева, В.Р. Сыртланов // Прикладная механика и техническая физика. - 2009. - Т. 50, № 4. - С. 100-111.

18. Шагапов, В.Ш. Математическая модель течения природного газа в трубопроводах с учетом диссоциации газогидратов / В.Ш. Шагапов, Н.Г. Мусакаев, Р.Р. Уразов // Инженерно-физический журнал. - 2008. - Т. 81, № 2. - С. 271-279. 
19. Бородин, С.Л. Численные методы решения задачи Стефана / С.Л. Бородин // Вестник Тюменского государственного университета. Физико-математическое моделирование. Нефть, газ, энергетика. - 2015. - Т. 1, № 3. - С. 164-175.

20. Бондарев, Э.А. Моделирование образования гидратов в газовых скважинах при их тепловом взаимодействии с горными породами / Э.А. Бондарев, И.И. Рожин, К.K. Аргунова // Инженерно-физический журнал. - 2014. - Т. 87, № 4. - С. 871-878.

Наиль Габсалямович Мусакаев, доктор физико-математических наук, Тюменский филиал Института теоретической и прикладной механики им. С.А. Христиановича СО РАН; Тюменский индустриальный университет (г. Тюмень, Российская Федерация), musakaev@ikz.ru.

Станислав Леонидович Бородин, кандидат физико-математических наук, Тюменский филиал Института теоретической и прикладной механики им. С.А. Христиановича СО РАН (г. Тюмень, Российская Федерация), borodin@ikz.ru.

Сергей Павлович Родионов, доктор физико-математических наук, Тюменский филиал Института теоретической и прикладной механики им. С.А. Христиановича СО РАН (г. Тюмень, Российская Федерация); Российский университет дружбы народов (г. Москва, Российская Федерация), rodionovsp@bk.ru.

Поступила в редакиию 21 ноября 2018 г. 